\title{
Ulkoa ohjattu aikuiskoulutus ja vapaa sivistystyö
}

\author{
Näkökulmia kansalaisopistoista inhimillisinä \\ aikuisten kasvuyhteisöinä
}

Reinikainen, Raimo. 1988. Ulkoa ohjattu aikuiskoulutus ja vapaa sivistystyö. Aikuiskasvatus 8,3. 23-26. Tässä artikkelissa pohditaan tieteellisteknisen, sosiologisen ja eettisen vallankumouksen asettamia haasteita ihmisen kehittämistarpeille muuttuvassa yhteiskunnassa sekä hahmotellaan humanistisiin arvolähtökohtiin tukeutuvan aikuisten kasvuyhteisön mahdollisia tunnuspiirteitä vaihtoehtona tai täydennyksenä keskitetysti ohjatulle aikuiskoulutukselle.

MOTTO:

Ihmiskunnan suurin vaara ei ole atomipommi, vaan lisääntyvä rappeuttava, taannuttava vapaa-aika (Andre Malraux — vap. muk. RR)

Artikkelilla pyritään myös herättämään keskustelua siitä, missä määrin vapaassa sivistystyössä toteutuvat ja ylipäätänsä hyväksytään prof. Aulis Alasen (1985) "naulaamat teesit".

— Käypä on ajan tasalla

- Irrationaalisuus myy hyvin

- Vaihtelua arkeen sekä

- Määrän tyrannia.

\section{Kolme vallankumousta}

Tarkastellessaan kysymystä ihmisen tulevaisuudesta ja kehittymistarpeista on $\mathrm{mm}$. prof. Joseph Basile todennut, että ensimmäistä kertaa ihmiskunnan historiassa ihmistä kohtaa yhtäaikaa kolme vallankumousta:

- Tieteellistekninen vallankumous, jossa aivomme korvaavat lihaksemme,

- Sosiologinen vallankumous: Koko maapallon väestölle tulee periaatteessa mahdolliseksi oppia ja arvioida asioita sekä osallistua yhteistoimintaan myös maailmanlaajuisella tasolla;

- Kolmanneksi ehkä merkittävin, eettinen vallankumous, jossa meidän perusarvomme - liittyivätpä ne sitten kotiin, uskontoon, isänmaahan tai kulttuuriarvoihimme, järkkyvät ja mitä todennäköisimmin muuttuvat globaalisessa, maailmanlaajuisessa kulttuuri- ja elinympäristössä.

Kehityssuuntaa paikalliskulttuureista tulevaisuuden maailmankulttuuriin apulaisprof. Martti Sarmela kuvaa varsin kriittisesti.
Sarmela vertaa suurteknologian läpimurtoa sotavarusteluun; Sekin uhkaa karata ihmisen hallinnasta ja teknoympäristönä tuhota kansalliset ja paikalliset kulttuurit.

Yksittäistä ihmistä nämä vallankumoukset koskettavat kolmella perusulottuvuudella: Ajattelussa - älyllisellä ja tiedollisella tasolla, toiseksi toiminnan tasolla - sosiaalisessa käyttäytymisessämme sekä kolmanneksi tunnetasolla - itsetietoisuudessamme.

Näiden perusulottuvuuksien - ajattelun, toiminnan ja tunteen epätasapaino ja rajutkin heilahtelut heijastavat sivilisaatiomme perustavaa laatua olevaa muutosprosessia, jossa älylliset, sosio-ekonomiset ja kulttuuriarvomme joutuvat uudelleen arvioitaviksi myös kasvatuksen näkökulmasta.

Sivilisaatiomme muutosprosessi nostaa esiin mm. seuraavanlaatuisia kasvatuksellisia kysymyksiä:

- Millaisten tietojen ja asenteiden varassa me etsimme ja rakennamme väylän tulevaisuuden yhteiskuntaan ja sivilisaatioon?

- Miten opimme kestämään lisääntyvät, ennalta-arvaamattomat tulevaisuusshokit?

- Kuinka ylipäätänsä kehitämme arviointikykyämme ja suhtautumistapojamme tulevaisuutemme suhteen. Kuinka voimme oppia käsittelemään ja hallitsemaan myös ennustamattomia asioita elämässämme?

- Kuinka opimmekaan tulevaisuudessa mikäli mahdollista - elämään onnellisina eli kaiken kaikkiaan pystymme vahvistamaan ajatteluamme, tunteemme ja toimintamme keskinäistä tasapainoa?

Ihmisen yhteiskunnalliseen, tuotannolliseen ja kulttuurielämään liittyvät muutostekijät ja kasvatukselliset tarpeet edellyttävät olemassa olevan (aikuis)koulutusjärjestelmämme laajaalaista ja perusteellista uudelleenarviointia. 
Seuraavassa pyrin tarkastelemaan asiaa hahmottelemalla joitakin ulkoaohjatun aikuiskoulutuksen ja itseohjautuvan sivistystoiminnan mahdollisia tunnuspiirteitä.

Kysymyksiä ihmisen tulevaisuudesta ja kasvatuksen merkityksestä on käsitelty viime vuosina mm. G.H. von Wrightin kirjassa Humanismi elämänasenteena ja emeritus prof. Urpo Harvan juhlakirjassa Humanistin teemojen tuntumassa.

\section{Keskitetystä koulutuksesta itseohjautuvaan sivistystyöhön}

Koko sivilisaatiomme vallankumouksellinen muutosprosessi ilmenee yhteiskunnallisena rakennemuutoksena, joka on edellyttänyt myös koulutustarjonnan kriittistä arviointia ja uudelleensuuntaamista.
Aikuiskoulutusjärjestelmämme uudistaminen, erityisesti ammatillisen aikuisopetuksen laajentaminen ammattioppilaitoksiin kurssiosastoina sekä ammattikurssikeskusten muuttaminen ammatillisiksi aikuiskoulutuskeskuksiksi tulevat merkittävästi edesauttamaan työikäisen väestömme ammatillisten perus- ja erityisvalmiuksien täydentämistä.

Toimialojen sisäiset muutokset ja koulutustarpeiden yksilöllistyminen ovat lisänneet voimakkaasti koulutuksen kysyntää ja aiheuttaneet aivan uusia koulutukseen kohdistuvia vaatimuksia.

Koulutettavien suuri määrä ja koulutustarpeiden moninaistuminen on havahduttanut myös hallinnon uuteen koulutusajatteluun. Keskitetysti ohjattu koulutustarjonta ei pysty vastaamaan todellisiin koulutustarpeisiin, vaan tarvitaan aikaisempaa nopeampaa, itseohjautuvaa säätelyä.

Kaavio 1. Ulkoa ohjatun aikuiskoulutuksen ja itseohjautuvan sivistystoiminnan tunnuspiirteitä

\begin{tabular}{|c|c|c|}
\hline $\begin{array}{l}\text { ULKOAOHJATTU } \\
\text { AIKUISKOULUTUS }\end{array}$ & & $\begin{array}{l}\text { ITSEOHJAUTUVA } \\
\text { SIVISTYSTOIMINTA }\end{array}$ \\
\hline $\begin{array}{l}\text { Yhteiskunta- ja } \\
\text { organisaatiokeskeinen } \\
\text { (Ihminen järjestelmän } \\
\text { välineenä) }\end{array}$ & LÄHTÖKOHTA & $\begin{array}{l}\text { Humanistinen } \\
\text { (Individualistinen ja } \\
\text { sosiaalinen lähtökohta, } \\
\text { "Ihminen arvo sinänsä") }\end{array}$ \\
\hline Koùlutuksen kohteina & $\begin{array}{l}\text { IHMISET JA } \\
\text { HEIDÄN } \\
\text { YHTEISÖNSÄ }\end{array}$ & Toiminnan subjekteina \\
\hline \multirow{2}{*}{$\begin{array}{l}\text { Sopeuttaa ihminen olemassa- } \\
\text { olevaan järjestelmään ja } \\
\text { hierarkioihin. }\end{array}$} & \multirow[t]{3}{*}{ PÄÄMÄÄRÄ } & Sivistynyt ihminen \\
\hline & & Yhteiskunnan inhimillistäminen \\
\hline $\begin{array}{l}\text { Valmentaa yhteiskunnalliseen } \\
\text { työnjakoon, tiettyihin } \\
\text { asemiin ja tehtäviin. }\end{array}$ & & $\begin{array}{l}\text { Poistaa yhteiskunnallisen työnjaon } \\
\text { ihmisille aiheuttamia tiedollisia ja } \\
\text { toiminnallisia raja-aitoja. }\end{array}$ \\
\hline $\begin{array}{l}\text { Muodollisten, yhtenäisten } \\
\text { tutkinto- ja pätevyys- } \\
\text { vaatimusten suorittaminen } \\
\text { Tiettyjen normien mukaisten } \\
\text { tietojen sekä ajattelu- ja } \\
\text { toimintamallien oppiminen }\end{array}$ & TAVOITTEET & $\begin{array}{l}\text { Ihmisten itsensä asettamat } \\
\text { tavoitteet } \\
\text { (toiminnan itsensä korostaminen, } \\
\text { normien erilaisuus) } \\
\text { Kokonaispersoonallisuuden } \\
\text { kehittyminen } \\
\text { (Ihminen kehittää todellisuus- } \\
\text { suhdettaan käytänöllisestä, } \\
\text { teoreettisesta, moraalisesta } \\
\text { ja esteettisestä näkökulmasta) }\end{array}$ \\
\hline $\begin{array}{l}\text { Rakentuu keskitetyn } \\
\text { suunnittelun ja } \\
\text { hallinnon varaan }\end{array}$ & $\begin{array}{c}\text { TOIMINNAN } \\
\text { SÄÄTELY }\end{array}$ & $\begin{array}{l}\text { Perusedellytyksenä } \\
\text { itseohjautuvuus }\end{array}$ \\
\hline
\end{tabular}

Perinteisen koulutusjärjestelmämme toimintaa ja vaihtoehtoista, itseohjautuvaa sivistystoimintaa yritän kuvata kaavion 1 avulla. Ulkoaohjattu koulutustoiminta on rakentunut keskitetyn suunnittelun ja hallinnon varaan, nähnyt ihmisen ensisijaisesti järjestelmän ja organisaatioiden välineenä ja koulutuksen kohteena, joka on pitänyt sopeuttaa vallitsevan yhteiskunnan hierarkioihin sekä työnjaon mukaisiin asemiin ja tehtäviin normitettujen kelpoisuus- 
vaatimusten mukaisesti. Ihmisten on todettu oppineen hahmottamaan työtään ja samalla koko elämäänsäkin varsin kapea-alaisesti ja puutteellisesti.

Ammatillisen koulutustoiminnan lisäksi myös yleissivistävässä opetustoiminnassa on ollut havaittavissa edellä kuvattuja ominaispiirteitä. Vapaa sivistystyö ei näytä kovinkaan suuresti poikkeavan ulkoaohjatun koulutuksen käytännöistä: Erityisesti taloudellisten resurssien keskitetty jako ja suuntaaminen tiettyihin erityistarkoituksiin tarkkoine rajoituksineen on oleellisesti vaikuttanut velvoiteluonteisen ja yhteiskunnan kannalta muuten arvostusta saavan paikkaavan ja täydentävän koulutuksen lisääntymiseen. Samalla on jouduttu tinkimään vapaalle sivistystyölle muotoutuneista omaehtoisuuden ja itsesäätelyn periaatteista.

Myös ns. informaatioyhteiskunnan kehitystä kuvaavissa ennusteissa (Lampinen ym.) korostuvat keskeiset ulkoa ohjatun koulutuksen perusnäkemykset:

- rationaalisuus tuotannossa ja yhteiskunnallisessa toiminnassa, kilpaisuushenkisyys valttia,

- tulevaisuus menneisyyden suoraviivaisena jatkeena,

- virallisesti hyväksytyn asiantuntijavallan korostaminen,

- ihminen rationaalisena, kilpailuhenkisenä, ammatillista ja yhteiskunnallista statusta tavoittelevana toimijana

- yhteiskunnan toiminnan asettaminen luonnon toiminnan edelle ja

- taloudellisen kasvun suosiminen.

Ulkoaohjatun koulutuksen suosimat ns. kovat arvot ovat aiheuttaneet vastareaktioita suorituskeskeistä tehokkuusyhteiskuntaa kohtaan. Vieraantuminen ja yleinen pahoinvointi hyvinvoinnin keskellä, teknologisten ja byrokraattisten koneistojen luoma tyhjyyden tunne, emotionaalisen ja sosiaalisen elämän köyhtyminen jne. ovat luomassa juurettomuutta ja paineita vaihtoehtoisen elämänmuodon etsimiseen.

Suoritusyhteiskunnan vasta-arvoihin perustuvassa omaehtoisen tulevaisuuden rakentamisessa korostuvat mm.

- kulutusideologiasta luopuminen ja yksinkertaisen elämänmuodon valinta,

- omavaraisuus yksilön ja lähiyhteisön elämässä,

- työn ja vapaa-ajan yhdistäminen,

- luonnon kunnioittaminen, uusiutuvien luonnonvarojen käytön korostuminen,

- vastuu lähimmäisistä lähellä ja kaukana, empatian korostaminen,

- epäusko asiantuntijoiden ja politiikkojen toimintaan ja ratkaisuihin sekä

— itsensä toteuttaminen kokonaisvaltaisesti.
Näistä vaihtoehtoisista arvoista on johdettavissa myös joitakin itseohjautuvan sivistystoiminnan keskeisiä tunnuspiirteitä.

Humanistinen, ihmiskeskeinen sivistysnäkemys korostaa ihmisen ja luonnon kunnioittamista, vastuuta toisista, kokonaispersoonallisuuden kehittämistä sekä yhteiskunnan inhimillistämistä mm. toimintarakenteita muuttamalla ja työnjaollisia raja-aitoja poistamalla.

\section{Kansalaisopistot inhimillisinä aikuiskasvatuskeskuksina?}

Kansalais- ja työväenopistojen, jotka ovat perinteisesti olleet vapaan sivistystyön laajin ja paikallisesti kattavin kulttuuri- ja sivistyslaitos, tulisi vakavasti ottaa arvioitavaksi sivilisaatiomme muutosprosessin uudet laaja-alaiset haasteet. Tältä pohjalta opistojen sivistystehtävä voitaisiin määrittää uudelleen.

Opistot voisivat toimia aikuisten paikallisina kasvuyhteisöinä, jotka toteuttaisivat itseohjautuvan sivistystoiminnan periaatteita ihmisten ja heidän lähiyhteisöjensä kehittymistarpeiden tyydyttämiseksi.

Tämä edellyttää opistolta nopeaa ja joustavaa muuntumiskykyä, halukkuutta uudistaa opetustoimintaansa sisällöllisesti ja menetelmällisesti mm. aluksi esittämäni Aulis Alasen mainitsemien "tehokkaan palvelun periaatteiden" osalta.

Todellinen sivistävä opetus merkitsee oppisisältöjen perinpohjaista uudistamista siten, että olennaisten tietojen omaksumisen ja hallinnan sekä käytännön taitojen ja toimintavalmiuksien lisäksi oppiminen kehittäisi asioiden ja ilmiöiden tutkimisen ja ongelmien ratkaisemisen taitoja sekä ihmisen kykyä suuntautua, asettaa elämälle uusia tavoitteita ja luoda uutta uskoa, toivoa tulevaisuuteen.

Aikuiskasvattajan etiikkaa käsitellessään Helena Kekkonen tiivistää mielestäni osuvasti tämän työmme keskeiset arvolähtökohdat. Hänen mukaansa käytännön opetustaidon osatekijöiden — suunnittelutaidon, sisällönhallinnan, esiintymis-, järjestely- ja havainnollistamis- sekä vuorovaikutus- ja ihmissuhdetaitojen - lisäksi ja koko kasvatustoiminnan perustaksi tarvitaan eettinen ajatusten, käsitysten ja toiminnan kokonaisuus, jonka olennaiset osatekijät ovat:

— kypsyys, "ihmisyys", elämän kunnioittaminen,

- vastuu yhteiskunnan jäsenenä, sosiaalisen oikeudenmukaisuuden toteuttaminen sekä

- solidaarisuus maailmankarısalaisena, "ihmiskunnan veljeys". 
Koska myös esteettisyys on ihmisen perusolemukseen kuuluva, kehittyvä osa-alue, jätettäköön lukijalle viestinä ja pohdiskelun käynnistäjänä japanilaisen teknisen korkeakoulun seinään kirjoitettu sanoma:

"Ensimmäinen esihistorian eläimellisyydestä uloskehittynyt ihminen oli se, joka poimi kukkia tehdäkseen kauniin kimpun, koska hän tajusi hyödyttömän hyödyllisyyden."

\section{Lähteitä}

Aikuiskasvatus 1/1988

Aikuiskoulutus 2000. Kansalaiskasvatuksen Keskuksen vuosikirja 1986.

Aikuiskoulutuksen arvot ja tavoitteet -seminaarin aineisto 17.-18.3.1988. Kansanvalistusseura: Helsinki

Aikuisten yhteiskunnallinen kasvatus 1988. Vapaan sivistystyön XXIX vuosikirja. Pieksämäki: Kirjastopalvelu.

Alanen, Aulis 1985. Tehokas palvelu aikuiskasvattajan ammatti-ideaalina. Teoksessa Manni \& Tuomisto (toim.), Humanistin teemojen tuntumassa. Acta Universitatis Tamperensis, ser. A. vol. 196.

Basile, Joseph 1984. Ihminen ja hänen koulutus- vaihtoehtonsa tulevaisuudessa. Ammattikasvatus — kunta — työelämä -konferenssin 7.-9.2.1984 kirjallista aineistoa. Suomen Kaupunkiliitto.

Educa, Kansalaiskasvatuksen Keskuksen vuosikirja 1987.

Elämänä kansansivistystyö. 1985. Vapaan sivistystyön XXVIII vuosikirja. Pieksämäki: Kirjastopalvelu

Eskola, Antti 1985. Persoonallisuustyypeistä elämäntapaan. WSOY: Juva.

Harva, Urpo 1983. Inhimillinen ihminen Homo Humanus. WSOY: Juva

Hirsjärvi, Sirkka 1985. Johdatus kasvatusfilosofiaan. Kirjayhtymä: Rauma

Kekkonen, Helena 1985. Aikuiskasvattajan etiikka. Teoksessa Manni \& Tuomisto (toim.), Humanistin teemojen tuntumassa. Acta Universitatis Tamperensisi, ser. A. vol. 196.

Lampinen - Savola - Välke-Salmi 1982. Koulutus käännekohdassa. Gummerus: Jyväskylä.

Lehtisalo - Raivola 1986. Koulutuspolitiikka ja koulutussuunnittelu. WSOY: Juva

Peltonen, Matti 1987. Koulutus 2000. Otava

Sarmela, Matti 1987. Uusi maailmankulttuuri ei tunne kansallisia eroja. Helsingin Sanomat 22.2.1987.

Wilenius, Reijo 1976. Kasvatuksen ehdot. Gummerus: Jyväskylä

von Wright, G.H. 1983. Humanismi elämänasenteena. Otava: Keuruu 
Reinikainen, Raimo. 1988. Externally directed adult education and liberal education. Viewpoints on Adult Education Centres as communities where adults can develop themselves.

The article deals with the challenges imposed by the techno-scientific, sociological and ethical revolution on human developmental needs in a changing society. The author goes on to outline probable characteristic features of a community for adult development, based on humanistic premises, as an alternative/supplement to centrally directed adult education. 